\title{
MẤY Ý KIẾN BƯớC ĐẦU VỀ SỐ TIỀN CỔ TÌM THẤY Ở THÔN PĂNG TIÊNG (XÃ LÁT, HUYỆN LẠC DƯƠNG, TỈNH LÂM ĐỒNG)
}

\author{
Cao Thế Trình ${ }^{\mathrm{a}^{*}}$, Nguyễn Huy Khuyến ${ }^{\mathrm{a}}$, Mai Minh Nhật ${ }^{\mathrm{b}}$
}

${ }^{a}$ Khoa Quốc tế học, Trường Đại học Đà Lạt, Lâm Đồng, Việt Nam

${ }^{b}$ Khoa Lịch sứ, Trường Đại học Đà Lạt, Lâm Đồng, Việt Nam

Nhận ngày 22 tháng 01 năm 2016

Chỉnh sửa ngày 30 tháng 01 năm 2016 | Chấp nhận đăng ngày 16 tháng 03 năm 2016

\section{Tóm tắt}

Trong nhũng năm gần đây, nhũng người dân thôn Păng Tiêng (xã Lát, huyện Lac Dương, tỉnh Lâm Đồng) đã tìm thấy hàng tạ tiền cổ tại địa phương, nhung rất tiếc, số tiền cổ đã bị thất thoát (bán phế liệu), chi còn lại một phần không đáng kể. Tù 416 đồng tiền cổ còn lưu lại, các tác giả đã xác minh được 42 hiệu tiền cồ, trong đó có một số hiệu tiền của Việt Nam (An Pháp nguyên bảo, Cảnh Hung thông bảo,...), còn lại là các hiệu tiền Trung Quốc (các hiệu tiền thời Đưòng, Ngũ đại thập quốc, Bắc Tống và Minh mạt-Thanh so'). Các tác giả cho rằng, khả năng lớn số tiền trên đây là do các quý tộc Chăm pa đã thu được trong các cuộc tấn công vào các phủ thành của chúa Nguyến vùng Thuận Thành vào cuối thế kỷ XVIII. Sau đó, để tránh sụ truy nã của quan quân chúa Nguyễn, ho lánh nạn lên vùng Păng Tiêng và truớc khi tỵ nạn sang Campuchia, họ đã chôn lại số tiền trên ở vùng này.

Từ khóa: Tiền cổ; Tiền cổ Việt Nam; Tiền cổ Trung Hoa; Tiền cổ tìm được ở Păng Tiêng; Tiền cổ ở Tây Nguyên.

Cho tới cuối thế kỷ XIX - đầu thế kỷ XX, Lâm Đồng nói riêng và toàn vùng Tây Nguyên nói chung, vẫn được biết đến như một khu vực phi tiền tệ. Trong một bài viết công bố trên Tạp chi Dân tộc học, số 3.1980, GS. Đặng Nghiêm Vạn đã khẳng định: “Ở Tây Nguyên xưa không thấy dấu vết của tiền tệ, kể cả những loại tiền rất quen thuộc với Đông Nam Á như tiền vỏ ốc Cauris Moneta hay tiền vòng đá, hoặc các loại tiền tệ của các quốc gia xung quanh. Rất nhiều vùng ở đây mãi đến năm 1945 còn khước từ đồng

\footnotetext{
*Tác giả liên hệ: Email: trinhct@dlu.edu.vn
} 
tiền Pháp" ". Chính nhận thức trên đây đã làm chúng tôi hết sức bất ngờ khi được tin tại thôn Păng Tiêng (xã Lát, huyện Lạc Dương, tỉnh Lâm Đồng), trong quá trình làm rẫy, người dân đã phát hiện ra hàng tạ đồng tiền cổ. Hiện tượng khác thường này đã thu hút sự quan tâm của chúng tôi - một nhóm nghiên cứu của Trường Đại học Đà Lạt. Chúng tôi đã tiến hành khảo sát thực địa và dưới đây, xin trình bày một số nhận thức bước đầu của mình liên quan tới số tiền cổ nói trên.

\section{VÀI NÉT VỀ SỐ TIỀN CỔ TÌM THẤY ĐƯợC TẠI PĂNG TIÊNG}

1.1. Vào trung tuần tháng 11.2015 , TS. Nguyễn ĐìnhTrung, Viện trưởng Viện nghiên cứu môi trường Trường Đại học Đà Lạt có tặng chúng tôi 32 đồng tiền đã gỉ sét và cho biết số tiền này là của một người dân tộc thiểu số ở thôn Păng Tiêng tìm được trong khi làm rẫy. Nhận thấy đây là một hiện tượng "không bình thường", nên một mặt chúng tôi tiến hành xác minh số tiền nói trên và mặt khác - chuẩn bị kế hoạch khảo sát thực tế. Sau khi làm sạch lớp gỉ sét, căn cứ vào các chữ Hán đúc nổi trên mặt các đồng tiền, chúng tôi xác minh được các loại tiền như trong Bảng 1.

\section{Bảng 1. Thống kê các loại tiền cổ từ Păng Tiêng}

do TS. Nguyễn Đình Trung cung cấp

\begin{tabular}{llllll}
\hline TT & Loại tiền & $\begin{array}{l}\text { Số } \\
\text { lượng } \\
\text { (đồng) }\end{array}$ & TT & Loại tiền & $\begin{array}{l}\text { Số } \\
\text { lượng } \\
\text { (đồng) }\end{array}$ \\
\hline 1 & $\begin{array}{l}\text { An Pháp nguyên bảo } \\
\text { 安法元寶 }\end{array}$ & 4 & 8 & $\begin{array}{l}\text { Thái Bình thánh bảo } \\
\text { 太平 通寶 }\end{array}$ & 1 \\
\hline 2 & $\begin{array}{l}\text { Gia Hựu thông bảo } \\
\text { 嘉 祐通寶 }\end{array}$ & 1 & 9 & $\begin{array}{l}\text { Thánh Nguyên thông bảo } \\
\text { 聖元通寶 }\end{array}$ & 2 \\
\hline 3 & $\begin{array}{l}\text { Hoàng Tống thông bảo } \\
\text { 皇宋通寶 }\end{array}$ & 1 & 10 & $\begin{array}{l}\text { Thánh Tông nguyên bảo } \\
\text { 聖宗元寶 }\end{array}$ & 2 \\
\hline 4 & $\begin{array}{l}\text { Hy Ninh nguyên bảo } \\
\text { 熙 寧元寶 }\end{array}$ & 1 & 11 & $\begin{array}{l}\text { Thiệu Thánh nguyên bảo } \\
\text { 紹聖元寶 }\end{array}$ & 1 \\
\hline 5 & $\begin{array}{l}\text { Khang Hy thông bảo } \\
\text { 康 熙 通寶 }\end{array}$ & 6 & 12 & $\begin{array}{l}\text { Tường Phù nguyên bảo } \\
\text { 祥苻元寶 }\end{array}$ & 2 \\
\hline
\end{tabular}

'Đặng Nghiêm Vạn, "Bàn về lịch sử tộc người và đặc điểm kinh tế, xã hội, văn hóa cư dân Tây Nguyên”, Tạp chi Dân tộc học, số $3 / 1980$, tr. 7 . 


\begin{tabular}{llllll}
\hline 6 & $\begin{array}{l}\text { Nguyên Hựu thông bảo } \\
\text { 元祐通寶 }\end{array}$ & 1 & 13 & $\begin{array}{l}\text { Trị Bình thánh bảo } \\
\text { 治 平聖寶 }\end{array}$ & 1 \\
\hline 7 & $\begin{array}{l}\text { Nguyên Phong thông bảo } \\
\text { 元豐通寶 }\end{array}$ & 6 & $*$ & Không đọc được & 3 \\
\hline
\end{tabular}

Trừ 3 đồng do quá mờ không đọc được, từ 29 đồng còn lại có thể đọc ra được 13 loại tiền, trong đó các loại tiền Thánh Nguyên thông bảo và An Pháp nguyên bảo là các hiệu tiền của Việt Nam, liên quan tới triều Hồ và triều $\mathrm{Mạc}^{2}$; loại tiền Nguyên Phong thông bảo là hiệu tiền vừa có ở Việt Nam (niên hiệu thứ 3 của vua Trần Thái Tông, từ 1251 - 1258), vừa có ở Trung Quốc (thời Tống Thần Tông, ở ngôi từ 1078 - 1085) và vừa có ở Nhật Bản (niên hiệu Vạn Trị thứ 2, tức 1659); các loại tiền còn lại đều liên quan tới các hiệu tiền của Trung Quốc, chủ yếu là các hiệu tiền thời Bắc Tống (từ thế kỷ IX - thế kỷ XI), chỉ có hiệu tiền Khang Hy thông bảo liên quan tới thời nhà Thanh (niên hiệu Khang Hy từ 1662 đến 1722). Đương nhiên, không thể căn cứ vào hiệu tiền để xác định niên đại, nhất là dưới thời phong kiến, tiền từ triều đại này vẫn được lưu thông, thậm chí còn được đúc lại ở các triều đại sau, tiền của Trung Quốc vẫn lưu hành trên thị trường Việt Nam. Vấn đề là, Păng Tiêng vốn là bon của người Cơ ho Srê, cho tới đầu thế kỷ XX vẫn còn khá biệt lập với thế giới bên ngoài và người dân chưa sử dụng tiền trong trao đổi buôn bán; vậy nguồn gốc của số tiền nói trên từ đâu, ai là chủ sở hữu của những "kho" tiền đó. Để trả lời câu hỏi này, không thể không tiến hành khảo sát xác minh tại địa phương.

1.2. Chúng tôi đã thông qua chính quyền địa phương (Phòng Văn hóa huyện Lạc Dương, UBND xã Lát) để kiểm tra thông tin, nhưng không ai hay biết gì đến vấn đề này. Kinh nghiệm cho biết, với những chuyện ít nhiều có tính nhạy cảm như trên, người dân thường từ chối tiết lộ thông tin vì e ngại bị liên lụy (tội tẩu tán, cố tình bán cổ vật trái phép). Trao đổi với chúng tôi, ông Rơ ông K' Síu - Chủ tịch UBND xã Lát xác nhận, thuở bé thi thoảng cũng có nhặt được một số ít tiền cổ, nhưng số lượng không đáng kể, nên không quan tâm.

\footnotetext{
${ }^{2}$ Đỗ Văn Ninh, Tiền cổ Việt Nam, NXB Khoa học xã hội, Hà Nội, 1992, tr. 65, 92
}

${ }^{3}$ Păng Tiêng giống như một thung lũng, xung quanh bao bọc bởi đồi núi và rừng già, cách trung tâm thành phố Đà Lạt khoảng 10 $\mathrm{km}$ về phía Tây Bắc theo đường chim bay. Tuy vậy, cho tới những thập niên 70 của thế kỷ trước, vùng đất này vẫn còn khá biệt lập, mỗi khi cần giao lưu với bên ngoài, người dân phải men theo những lối mòn vượt núi. Trong những thập niên gần đây, đường ô-tô từ Đà Lạt đã vươn tới tận thôn (chiều dài khoảng $25 \mathrm{~km}$ ), trong đó có một số đoạn phải bạt núi với ta-luy cao tới cả chục mét. 
Kết quả khảo sát trực tiếp của chúng tôi tại địa bàn thôn Păng Tiêng cũ cho thấy, cách đây $6-7$ năm về trước, người dân địa phương đã phát hiện ra rất nhiều tiền cổ và họ đã bán phế liệu cho những người đến từ Lâm Hà với giá chỉ 5.000 - 6.000 đồng/kg. Riêng gia đình bà Me Quýt đã đào được hơn 1 tạ. Ông Dacat Bress - người dân tộc Cơ ho, sinh năm 1966 tại bon Păng Tiêng (sau này lấy vợ và cư trú tại thôn Măng Lin, Phường VII, Đà Lạt) cho biết: Thuở bé, ông cũng đã nhặt được tại rẫy nhà mình nhiều đồng tiền xu cổ, sau đó làm thất lạc hết. Anh Nguyễn Sỹ Vinh - người Kinh (sinh năm 1988, cùng với gia đình mua đất và cư trú tại địa phương) kể lại: Khoảng 8 năm trước trong lúc cuốc cỏ cà phê, anh đã phát hiện ra một hố chôn tiền dưới gốc cây. Anh đã bốc và nhét đầy cả 2 chiếc ủng (vật dụng người dân ở đây vẫn thường dùng đi khi làm rẫy), sau đó bán phế liệu. Anh còn chỉ cho chúng tôi chỗ anh phát hiện ra tiền cổ, nay đã san phẳng để trồng cà phê. Chúng tôi còn được giới thiệu gặp anh Hải, người vừa mới đào được một xâu tiền tại rẫy nhà mình vào cuối năm 2015. Tuy nhiên, số tiền đó anh đã cho mấy cháu nhỏ ở Lâm Hà, trong nhà chỉ sót lại 2 đồng. Đó là 2 đồng Khang $H y$ thông bảo và Nguyên Hưu thông bảo - loại tiền tương tự như tiền TS. Nguyễn Đình Trung đã cho chúng tôi. Những người dân địa phương còn cho biết thêm, ngoài loại tiền nhỏ, họ còn tìm thấy một số đồng tiền lớn với đường kính trên dưới 50 mm, nhưng cũng đã cho người khác. Ngoài ra, họ còn kể lại khá nhiều chuyện ly kỳ liên quan tới việc tìm ra tiền cổ ở đây, như trước cửa hang chôn tiền có con rắn cạp nong to bằng bắp chân, nên không ai dám động tới; anh Nguyễn Sỹ Vinh sau khi nhặt được đầy 2 ủng tiền, đi được mấy bước thì ngã lăn ra, không biết gì nữa... Theo chị gái anh, "lúc đó tự nhiên cậu ấy khóc hu hu, mọi người phải mang ủng tiền lại chỗ lấy được khấn xin mãi, cậu mới tỉnh lại”...

Đáng lưu ý hơn cả là thông tin từ anh Đàm Văn Quang, người dân tộc Thái ở Tùng Nghĩa (Đức Trọng), lấy vợ là chị Kơ sa K’Thị, người dân tộc Cơ ho, sống tại thôn Păng Tiêng. Ngoài tiền cổ, anh còn tìm thấy một thanh kiếm cổ và đã bán cho một người ở Bảo Lộc (nhưng có người lại bảo là hiện đang ở Phan Rang, rõ ràng, họ không muốn tiết lộ thông tin về người mua). Rất may, thanh kiếm đó đã từng rao bán trên mạng với những hình ảnh khá chi tiết (xem hình 1) đã giúp cho việc nhận diện về nó. Đó là một thanh kiếm dài hơn $50 \mathrm{~cm}$, chuôi $15 \mathrm{~cm}$ (ước lượng theo chiều dài vỏ bao 
thuốc lá Craven $A$ để cạnh). Điều dễ nhận thấy là chuôi kiếm có hình thù tạo nên sự liên tưởng tới đầu mãng xà, hoàn toàn khác với chuôi kiếm kiểu Việt Nam hay Trung Hoa. Theo chúng tôi, loại chuôi kiếm kiểu này gần với kiếm Thái Lan - nơi mà người ta tôn thờ rắn thần Naga.

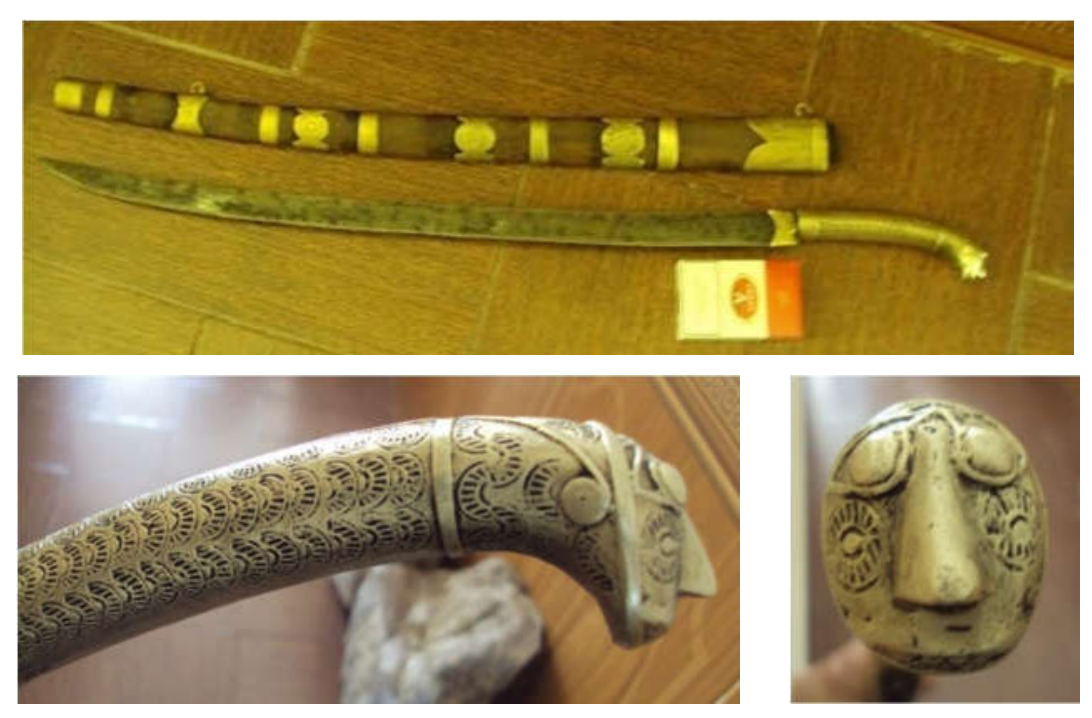

\section{Hình 1. Kiếm tìm thấy ở Păng Tiêng (hình trên), chuôi kiếm (hình dưới, bên trái) và đầu chuôi kiếm (hình dưới, bên phải)}

Chị K' Thị - vợ anh Quang, còn cho biết, cách đây mấy năm, chị đã tìm thấy rất nhiều tiền cổ, đựng đầy một bao tải, nhưng đã bán đồng phế liệu, chỉ giữ lại một ít để "làm kỷ niệm". Khi biết chúng tôi là pô gru ("thầy giáo" - theo tiếng Cơ ho) muốn tìm hiểu về lịch sử, văn hóa địa phương, chị tặng chúng tôi toàn bộ số tiền nói trên (cân lên được đúng $1 \mathrm{~kg}$ và đếm được 382 đồng, xem hình 2).

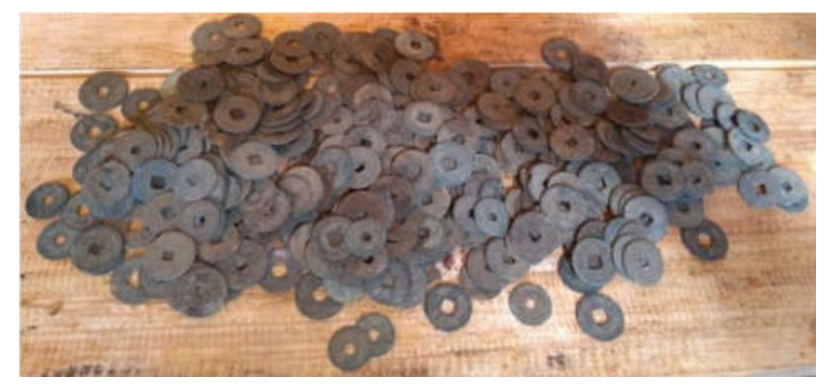

\section{Hình2: Một phần tiền cổ ở Păng Tiêng do gia đình chị Kơ sa K'Thị tìm thấy}

Tương tự lần trước, sau khi làm sạch, trừ 32 đồng do quá mờ, chúng tôi đọc ra được 42 hiệu tiền khác nhau, trong đó có 13 hiệu tiền trùng với số tiền anh Trung đã tặng hôm trước. Tổng hợp cả 2 đợt và 2 đồng lẻ từ anh Hải cho, chúng tôi hiện đã thu 
thập được 416 đồng tiền. Căn cứ vào hiệu tiền, chúng tôi lập thành bảng tổng hợp như trong Bảng 2.

\section{Bảng 2. Thống kê các loại tiền cổ từ Păng Tiêng}

(Hiện đang được lưu trữ tại Kho tư liệu khoa Quốc tế học, Trường Đại học Đà Lạt)

\begin{tabular}{|c|c|c|c|}
\hline $\mathrm{TT}$ & Loại tiền & SL & Đặc điểm \\
\hline 1 & $\begin{array}{l}\text { An Pháp nguyên bảo } \\
\text { 安法元寶 }\end{array}$ & 27 & tạp thư, đọc vòng, $2 \mathrm{r}^{4}=21,5 \mathrm{~mm}$ \\
\hline 2 & $\begin{array}{l}\text { Càn Nguyên trọng bảo } \\
\text { 乾元重寶 }\end{array}$ & 1 & chữ chân, đọc chéo, $2 \mathrm{r}=23,3 \mathrm{~mm}$ \\
\hline 3 & $\begin{array}{l}\text { Cảnh Đức nguyên bảo } \\
\text { 景德元寶 }\end{array}$ & 5 & chữ chân, đọc vòng, $2 \mathrm{r}=24,3 \mathrm{~mm}$ \\
\hline 4 & $\begin{array}{l}\text { Cảnh Hưng thông bảo } \\
\text { 景興通寶 }\end{array}$ & 3 & $\begin{array}{l}2 \text { đồng chữ chân, } 1 \text { đồng chữ triện, } \\
\text { đọc chéo, } 2 \mathrm{r}=25 \mathrm{~mm}\end{array}$ \\
\hline 5 & $\begin{array}{l}\text { Cảnh Hựu nguyên bảo } \\
\text { 景 祐元寶 }\end{array}$ & 3 & chữ chân, đọc vòng, $2 \mathrm{r}=25$ mm \\
\hline 6 & $\begin{array}{l}\text { Chí Hòa nguyên bảo } \\
\text { 至和元寶 }\end{array}$ & 1 & chữ chân, đọc vòng, $2 \mathrm{r}=24,3 \mathrm{~mm}$ \\
\hline 7 & $\begin{array}{l}\text { Chí Hòa thông bảo } \\
\text { 至和通寶 }\end{array}$ & 1 & chữ chân, đọc chéo, $2 \mathrm{r}=25 \mathrm{~mm}$ \\
\hline 8 & $\begin{array}{l}\text { Chí Đạo nguyên bảo } \\
\text { 至道元寶 }\end{array}$ & 1 & tạp thư, đọc vòng, $2 \mathrm{r}=24,5 \mathrm{~mm}$ \\
\hline 9 & $\begin{array}{l}\text { Chính Hòa thông bảo } \\
\text { 政 和通寶 }\end{array}$ & 1 & chữ triện, đọc chéo, $2 \mathrm{r}=24 \mathrm{~mm}$ \\
\hline 10 & $\begin{array}{l}\text { Chu Nguyên thông bảo } \\
\text { 周元通寶 }\end{array}$ & 1 & chữ chân, đọc chéo, $2 \mathrm{r}=22,5 \mathrm{~mm}$ \\
\hline 11 & $\begin{array}{l}\text { Hàm Bình nguyên bảo } \\
\text { 咸平元寶 }\end{array}$ & 5 & chữ chân, đọc vòng, $2 \mathrm{r}=23,5 \mathrm{~mm}$ \\
\hline 12 & $\begin{array}{l}\text { Hàm Thiệu nguyên bảo } \\
\text { 咸邵元寶 }\end{array}$ & 1 & chữ chân, đọc vòng, $2 \mathrm{r}=20$ mm \\
\hline 13 & $\begin{array}{l}\text { Hán Nguyên thông bảo } \\
\text { 漢元通寶 }\end{array}$ & 1 & chữ chân, đọc chéo, $2 \mathrm{r}=21,2$ mm \\
\hline 14 & $\begin{array}{l}\text { Hoàng Tống thông bảo } \\
\text { 皇宋通寶 }\end{array}$ & 23 & $\begin{array}{l}12 \text { đồng chữ chân, } 11 \text { đồng chữ } \\
\text { triện, đọc chéo, } 2 \mathrm{r}=24,7 \mathrm{~mm}\end{array}$ \\
\hline 15 & $\begin{array}{l}\text { Hy Ninh nguyên bảo } \\
\text { 熙 寧元寶 }\end{array}$ & 13 & $\begin{array}{l}8 \text { đồng chữ chân, } 3 \text { đồng chữ triện, } 2 \\
\text { đồng tạp thư, đọc vòng, } 2 \mathrm{r}=24 \mathrm{~mm}\end{array}$ \\
\hline 16 & $\begin{array}{l}\text { Đại Hòa thông bảo } \\
\text { 大和通寶 }\end{array}$ & 3 & chữ chân, đọc chéo, $2 \mathrm{r}=21,1 \mathrm{~mm}$ \\
\hline
\end{tabular}

\footnotetext{
${ }^{4} 2 \mathrm{r}=$ Đường kính của đồng tiền
} 


\begin{tabular}{|c|c|c|c|}
\hline 17 & $\begin{array}{l}\text { Gia Hựu thông bảo } \\
\text { 嘉 祐通寶 }\end{array}$ & 3 & chữ chân, đọc chéo, $2 r=24,5$ mm \\
\hline 18 & $\begin{array}{l}\text { Khai Nguyên thông bảo } \\
\text { 開元通寶 }\end{array}$ & 10 & chữ chân, đọc chéo, $2 r=24$ mm \\
\hline 19 & $\begin{array}{l}\text { Khang Hy thông bảo } \\
\text { 康熙通寶 }\end{array}$ & 74 & $\begin{array}{l}\text { chữ chân, đọc chéo, } 54 \text { đồng bằng } \\
\text { đồng đỏ, } 20 \text { đồng tiền kẽm, } 2 \mathrm{r}= \\
24,5 \mathrm{~mm}\end{array}$ \\
\hline 20 & $\begin{array}{l}\text { Lợi Dụng thông bảo } \\
\text { 利用 通寶 }\end{array}$ & 1 & chữ chân, đọc chéo, $2 r=24,3$ mm \\
\hline 21 & $\begin{array}{l}\text { Nguyên Hựu thông bảo } \\
\text { 元祐通寶 }\end{array}$ & 23 & $\begin{array}{l}9 \text { dồng tạp thư, } 14 \text { đồng chữ chân, } \\
\text { đọc vòng, } 2 \mathrm{r}=21,5 \mathrm{~mm}, 25 \mathrm{~mm}\end{array}$ \\
\hline 22 & $\begin{array}{l}\text { Nguyên Phong thông bảo } \\
\text { 元豐通寶 }\end{array}$ & 70 & $\begin{array}{l}25 \text { đồng chữ khải, } 16 \text { đồng chữ triện, } \\
29 \text { đồng chữ chân ( } 4 \text { đồng có chữ } \\
\text { thông "hổ vî"), đọc vòng, } 2 \mathrm{r}=24 \text {, } \\
21,4 \text { và } 21,3 \mathrm{~mm} \text { (hổ vĩ) }\end{array}$ \\
\hline 23 & $\begin{array}{l}\text { Nguyên Phù thông bảo } \\
\text { 元苻通寶 }\end{array}$ & 2 & tạp thư, đọc vòng, $2 \mathrm{r}=21,4 \mathrm{~mm}$ \\
\hline 24 & $\begin{array}{l}\text { Thái Bình thánh bảo } \\
\text { 太平聖 寶 }\end{array}$ & 6 & chữ chân, đọc chéo, $2 r=21,2$ mm \\
\hline 25 & $\begin{array}{l}\text { Thái Bình thông bảo } \\
\text { 太平 通寶 }\end{array}$ & 1 & chữ chân, đọc chéo, $2 r$ = 24 mm \\
\hline 26 & $\begin{array}{l}\text { Thánh Nguyên thông bảo } \\
\text { 聖元通寶 }\end{array}$ & 12 & chữ triện, đọc chéo, $2 \mathrm{r}=21,4 \mathrm{~mm}$ \\
\hline 27 & $\begin{array}{l}\text { Thánh Tông nguyên bảo } \\
\text { 聖宗元寶 }\end{array}$ & 16 & $\begin{array}{l}10 \text { đồng chữ triện, } 6 \text { đồng chữ khải, } \\
\text { đọc vòng, } 2 \mathrm{r}=24,1 \mathrm{~mm}\end{array}$ \\
\hline 28 & $\begin{array}{l}\text { Thiên Hy thông bảo } \\
\text { 天禧通寶 }\end{array}$ & 2 & $\begin{array}{l}\text { chữ chân, đọc vòng, } 2 \mathrm{r}=24,3 \mathrm{~mm} \\
\text { và } 25,5 \mathrm{~mm}\end{array}$ \\
\hline 29 & $\begin{array}{l}\text { Thiên Phù nguyên bảo } \\
\text { 天苻元寶 }\end{array}$ & 1 & chữ chân, đọc vòng, $2 r=20,6$ mm \\
\hline 30 & $\begin{array}{l}\text { Thiên Thánh nguyên bảo } \\
\text { 天聖元寶 }\end{array}$ & 15 & $\begin{array}{l}3 \text { dồng chữ chân, } 8 \text { đồng tạp thư, } 4 \\
\text { đồng chữ lệ, đọc vòng, } 2 \mathrm{r}=24,5 \\
\mathrm{~mm}, 22 \mathrm{~mm} \text { và } 21 \mathrm{~mm}\end{array}$ \\
\hline 31 & $\begin{array}{l}\text { Thiệu Bình nguyên bảo } \\
\text { 紹平元寶 }\end{array}$ & 4 & chữ chân, đọc chéo, $2 r=23$ mm \\
\hline 32 & $\begin{array}{l}\text { Thiệu Phong bình bảo } \\
\text { 紹豐平寶 }\end{array}$ & 6 & $\begin{array}{l}2 \text { đồng chữ chân, } 4 \text { dồng tạp thư, } \\
\text { đọc vòng, } 2 \mathrm{r}=20,4 \mathrm{~mm}\end{array}$ \\
\hline 33 & $\begin{array}{l}\text { Thiệu Phong nguyên bảo } \\
\text { 紹豐元寶 }\end{array}$ & 2 & tạp thư, đọc vòng, $2 \mathrm{r}=21,6 \mathrm{~mm}$ \\
\hline 34 & $\begin{array}{l}\text { Thiệu Thánh nguyên bảo } \\
\text { 紹聖元寶 }\end{array}$ & 13 & $\begin{array}{l}8 \text { đồng tạp thư, } 5 \text { đồng chữ khải, đọc } \\
\text { vòng, } 2 \mathrm{r}=24 \mathrm{~mm}\end{array}$ \\
\hline 35 & $\begin{array}{l}\text { Thuần Hóa nguyên bảo } \\
\text { 淳化元寶 }\end{array}$ & 1 & chữ khải, đọc vòng, $2 \mathrm{r}=24,4 \mathrm{~mm}$ \\
\hline
\end{tabular}




\begin{tabular}{llcl}
\hline 36 & 1 & $\begin{array}{l}\text { Thuân Trị thông bảo } \\
\text { 順治通寶 }\end{array}$ & chữ chân, đọc chéo, $2 \mathrm{r}=22 \mathrm{~mm}$ \\
\hline 37 & $\begin{array}{l}\text { Trị Bình thánh bảo } \\
\text { 治 平聖寶 }\end{array}$ & 11 & $\begin{array}{l}\text { 6 đồng chữ triện, } 5 \text { đồng chữ chân, } \\
\text { đọc vòng, } 2 \mathrm{r}=21 \mathrm{~mm}\end{array}$ \\
\hline 38 & $\begin{array}{l}\text { Trị Bình thông bảo } \\
\text { 治 平通寶 }\end{array}$ & 1 & chữ chân, đọc chéo, $2 \mathrm{r}=24 \mathrm{~mm}$ \\
\hline 39 & $\begin{array}{l}\text { Tường Nguyên thông bảo } \\
\text { 祥元通 寶 }\end{array}$ & 3 & tạp thư, đọc chéo, $2 \mathrm{r}=22 \mathrm{~mm}$ \\
\hline 40 & $\begin{array}{l}\text { Tường Phù nguyên bảo } \\
\text { 祥苻元寶 }\end{array}$ & 4 & chữ chân, đọc vòng, $2 \mathrm{r}=24,7 \mathrm{~mm}$ \\
\hline 41 & $\begin{array}{l}\text { Tường Phù thông bảo } \\
\text { 祥苻通寶 }\end{array}$ & 7 & chữ chân, đọc vòng, $2 \mathrm{r}=24 \mathrm{~mm}$ \\
\hline 42 & $\begin{array}{l}\text { Tường Thánh thông bảo } \\
\text { 祥聖通寶 }\end{array}$ & 2 & chữ chân, đọc vòng, $2 \mathrm{r}=21,5 \mathrm{~mm}$ \\
\hline$*$ & Không đọc được & 35 & \\
\hline Tổng cộng & 416 & \\
\hline
\end{tabular}

Như vậy, có thể khẳng định thôn Păng Tiêng đã từng là nơi chôn giấu một lượng tiền cổ khá lớn, có thể lên tới hàng tạ. Rất tiếc, do thiếu hiểu biết, người dân địa phương đã để thất thoát một khối lượng lớn cổ vật có thể góp phần soi sáng nhiều vấn đề liên quan tới lịch sử và văn hóa của Lâm Đồng nói riêng và toàn vùng Tây Nguyên nói chung. Qua 416 đồng tiền hiện có với kích thước và độ dày mỏng không đồng đều (đường kính dao động từ $20-25 \mathrm{~mm}$, độ dày dao động từ $0,6-1,5 \mathrm{~mm}$ ), chất liệu không đồng nhất (có loại đồng đỏ, có loại đồng thau hay tiền kẽm), thư pháp khác nhau (chữ chân, chữ triện, chữ khải, tạp thư) và sự khác nhau đó thể hiện ngay trong một hiệu tiền... có thể nhận định đây là số tiền phong phú về niên đại, đa dạng về loại hình, được tích lũy từ các loại tiền từng lưu hành trên thị trường nước ta cách đây trên dưới 3 thế kỷ, được đúc vào những thời điểm và tại những cơ sở đúc tiền khác nhau, không loại trừ có cả những đồng được đúc tại Trung Quốc và Nhật Bản, tuy nhiên chủ yếu vẫn là những sản phẩm do các xưởng tiền ở Đàng Trong đã đúc trong các thế kỷ XVII XVIII. Theo lời người dân địa phương, ít nhất có 3 địa điểm chôn tiền cách nhau không $\mathrm{xa}$, trong phạm vi trên dưới $1,5 \mathrm{~km}^{2}$. Có nhiều dấu hiệu chứng tỏ số tiền này không phải đang được lưu thông với tư cách là vật ngang giá trong trao đổi hàng hóa tại địa phương, mà được chôn cất vì một mục đích nào đó. Vấn đề là nguồn gốc của số tiền nói trên, ai là chủ sở hữu của số tiền đó, chúng được đem đến đây chôn vào thời gian nào và 
mục đích cất giấu là gì? Dưới đây chúng tôi mạnh dạn trao đổi một số suy nghĩ bước đầu liên quan tới những câu hỏi vừa nêu.

\section{VÀI SUY NGHĨ BƯớC ĐẦU VỀ SỐ TIỀN CỔ Ở PĂNG TIÊNG}

Như đã nói ở trên, số tiền cổ ở Păng Tiêng bị thất thoát là rất lớn, tuy nhiên với số lượng mà chúng tôi đã thu thập được, vẫn có thể nêu lên một số nhận định sơ bộ với hy vọng sẽ giúp cho việc nghiên cứu tiếp theo.

2.1. Tổng hợp lại số tiền cổ sưu tập được và dựa vào sự không trùng lặp với các hiệu tiền cổ Trung Quốc, có thể nhận ra 6 hiệu tiền của các triều đại phong kiến Việt Nam. Đó là các hiệu tiền Thiệu Phong nguyên bảo, Thiệu Phong bình bảo (thời Trần), Thánh Nguyên thông bảo (thời Hồ), Đại Hòa thông bảo (thời Lê sơ), An Pháp nguyên bảo (thời Mạc) và Cảnh Hung thông bảo (thời Lê trung hưng). Các loại tiền còn lại đều là các hiệu tiền Trung Quốc, gồm 2 hiệu tiền thời Đường (Khai Nguyên thông bảo và Càn Nguyên trọng bảo), 2 hiệu tiền thời Ngũ đại thập quốc (Hán Nguyên thông bảo và Chu Nguyên thông bảo), 16 hiệu tiền thời Bắc Tống (các thế kỷ X - XII) và 3 hiệu tiền thuộc thời Minh mạt-Thanh sơ (Lọi dụng thông bảo, Thuận Trị thông bảovà Khang Hy thông bảo, trong đó hiệu tiền Khang Hy thông bảo - theo các nhà sưu tập tiền cổ, được đúc vào dịp sinh nhật của vua Khang Hy năm $1713^{5}$. Ngoài ra, có 5 hiệu tiền vừa có ở Việt Nam, vừa có ở Trung Quốc (Trị Bình thông bảo, Nguyên Phong thông bảo, Thái Bình thông bảo, Thiên Thánh nguyên bảo, Chính Hòa thông bảo) và 8 hiệu tiền không xác định, hay nói như các nhà cổ tiền học là "unknown", "vô khảo phẩm”, "không chính triều"... như Hàm Thiệu nguyên bảo, Tưòng Nguyên thông bảo, Tưòng Thánh thông $b a ̉ o, \ldots$ Những hiệu tiền "unknown" này không bắt gặp trong danh mục tiền cổ Trung Quốc, hầu như chỉ tìm thấy ở phía Nam đất nước, nên có thể xem là tiền được đúc dưới thời các chúa Nguyễn ở Đàng trong từ thế kỷ XVI - XVIII. Hiệu tiền Nguyên Phong thông bảo có số lượng lớn, nhưng rất khó xác định là của Việt Nam, Trung Quốc hay Nhật Bản. Trong số 70 đồng tiền loại này, có 4 đồng có nét quai xước của chữ "thông" vắt lên như “đuôi hổ” (chữ Hán gọi là 元豐通寶虎尾通“Nguyên Phongthông bảo hổ vĩ 
thông") - một dấu hiệu mà các nhà cổ tiền học Việt Nam và Trung Quốc đều xác nhận là tiền Nguyen Phong của Việt Nam thời nhà Trần ${ }^{6}$ (xem hình 3).
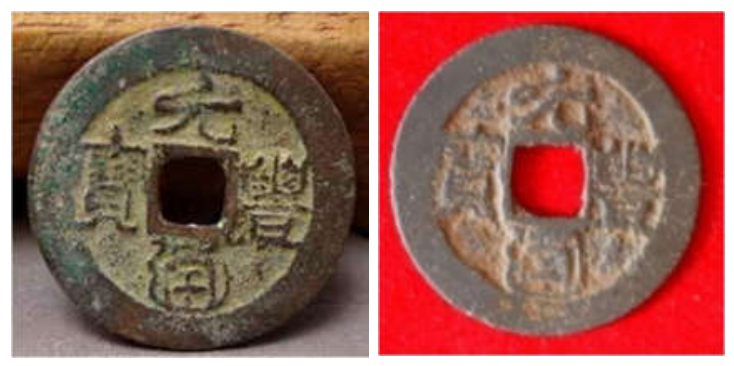

\section{Hình 3. Đồng tiền Nguyên Phong thông bảo có nét quai xước hình "hổ vî" tìm thấy ở Păng Tiêng (phải) và hình đồng tiền cùng loại sưu tầm trên internet (trái)}

Tuy nhiên, như đã nói ở trên, không thể căn cứ vào hiệu tiền để xác định niên đại, bởi dưới thời phong kiến, tiền từ triều đại này vẫn được lưu thông, thậm chí còn được đúc lại ở các triều đại sau. Cụ thể hơn, vào thế kỷ XVIII, khi đất nước còn bị phân liệt thành Đàng trong và Đàng ngoài, ở phía Nam đất nước có các xưởng đúc tiền phỏng theo các hiệu tiền lưu hành phổ biến thời đó ở Việt Nam và Trung Quốc. Đó là các xưởng đúc của chúa Nguyễn Phúc Thụ từ 1725 và của các chúa Nguyễn sau đó (1736 1802), xưởng đúc tiền của các vương triều Tây Sơn và xưởng đúc tiền của Mạc Thiên Tứ ở Hà Tiên (1736), trong đó có cả các hiệu tiền trong bảng thống kê của chúng tôi ${ }^{7}$. Tuy nhiên, có mấy điểm cần lưu ý:

- Trong số 42 loại tiền nói trên, hiệu tiền có niên đại muộn nhất thuộc về loại tiền Cảnh Hưng thông bảo. Đây là loại tiền được đúc dưới thời vua Lê Hiển tông, niên hiệu Cảnh Hưng (1740 - 1786). Cần lưu ý thêm, các hiệu tiền Cảnh Hưng (khoảng 30 loại tiền cỡ nhỏ với các vĩ tố thông bảo, trung bảo, chí bảo, vĩnh bảo, đại bảo, cụ bảo...) là hiệu tiền rất thịnh hành ở Đàng ngoài trong thế kỷ thứ

\footnotetext{
${ }^{6}$ Phạm Quốc Quân (chủ biên), Tiền kim loại Việt Nam, Bảo tàng Lịch sử Việt Nam xuất bản, Hà Nội, 2005, tr. 21, có đối chiếu với các tiêu bản số 042,043 và 044 của cuốn sách ở trang 164 và website:

http://www.taobao.com/product/\%E5\%85\%83\%E8\%B1\%90\%E9\%80\%9A\%E5\%AF\%B6.html.

${ }^{7}$ Danh muc tiền cổ Việt Nam của nhà sưu tập tiền cổ nổi tiếng xứ Huế - Bác sỹ Nguyễn Anh Huy tại địa chỉ website: http://library.buh.edu.vn/resources/docs/pdf/danh_muc_tien_co_viet_nam.pdf.
} 
XVIII, thậm chí được xem là "hiện tượng” trong lịch sử tiền tệ Việt Nam", song trong số 416 đồng tiền cổ tìm thấy ở Păng Tiêng, chỉ bắt gặp 3 đồng thuộc hiệu tiền này.

- Trong số các loại tiền nói trên, không có các hiệu tiền của các vương triều Tây Sơn (Thái Đức/Minh Đức thông bảo, Quang Trung thông bảo/đại bảo, Cảnh Thịnh thông bảo/đại bảo,...) cũng như các hiệu tiền của các vua triều Nguyễn ở thế kỷ XIX (như Gia Long thông bảo, Minh Mạng thông bảo, Thiệu Trị thông bảo, Tụ̣ Đức thông bảo...).

Từ những điểm vừa nêu cũng như căn cứ vào lịch sử khu vực và thái độ thờ ơ của những người Cơ ho địa phương với tiền cổ, có thể suy luận, số tiền nói trên không phải của tổ tiên các cư dân đã có mặt từ lâu ở vùng này. Số tiền đó tương tự với các loại tiền cổ đã phát hiện trong những thập kỷ gần đây ở các tỉnh duyên hải Nam Trung Bộ (Phú Yên, Bình Định) với số lượng lên tới cả tấn ${ }^{9}$. Điều đó chứng tỏ, nguồn gốc số tiền cổ ở Păng Tiêng có liên quan tới những cư dân ở vùng đồng bằng phía Nam đất nước. Họ đã đem lên đây chôn cất vào khoảng cuối thế kỷ XVIII hoặc muộn nhất là đầu thế kỷ XIX. Chủ sở hữu số tiền nói trên dường như không có các mối quan hệ với các vương triều Lê-Trịnh ở Đàng ngoài, Tây Sơn ở Đàng trong và cả vương triều Nguyễn sau này.

2.2. Về mục đích chôn tiền: Thông thường, những người giàu có thường chôn tiền trong vò, trong hũ bằng sành với mục đích để dành cho con cháu, song tại Păng Tiêng, những người phát hiện đều xác nhận là tiền được chôn trong hang, trong hố (sau đó trồng cây để đánh dấu, nên họ đã thấy ở dưới gốc cây?) mà không hề có bình hay lọ đựng tiền. Từ đó có thể suy luận, số tiền cổ ở Păng Tiêng có thể được đựng trong bao vải, sau một thời gian dài hàng thế kỷ, các bao vải đã bị mục nát, không còn dấu vết. Điều đó chứng tỏ, chủ nhân (hay các chủ nhân) của số tiền nói trên không có mục đích cất trữ lâu dài, mà chỉ chôn tạm để một thời gian không lâu có thể lấy lại. Không loại trừ

\footnotetext{
${ }^{8}$ Đỗ Văn Ninh, Sách đã dẫn, tr. 99 - 120.
}

${ }^{9}$ http://tuoitre.vn/tin/chinh-tri-xa-hoi/20041228/phu-yen-phat-hien-hon-300kg-tien-co/61481.html; 
chủ nhân (hay các chủ nhân) nói trên đang trên một lộ trình dài (sang Campuchia chẳng hạn), vì số tiền mang theo quá nặng và nơi định tới không sử dụng những loại tiền này, nên phải chôn lại. Những biến đổi khách quan của hoàn cảnh tiếp sau đã không cho phép chủ nhân (hay các chủ nhân) số tiền trên trở lại lấy số tiền của mình, và cũng không loại trừ chủ nhân (hay các chủ nhân) đó đã qua đời vì những nguyên nhân nào đó.

2.3. Về thời gian xuất hiện của tiền cổ ở Păng Tiêng: Sự có mặt của hiệu tiền Cảnh Hung thông bảo chứng tỏ thời gian chôn tiền ở Păng Tiêng không thể sớm hơn năm đầu phát hành loại tiền này (1740). Sự vắng mặt của các hiệu tiền của các vương triều Tây Sơn được đúc trong những năm 1787 - 1801, và nhất là sự thiếu vắng các hiệu tiền của các vua triều Nguyễn sau này, cho phép suy luận thời gian muộn nhất của số tiền nói trên là đầu thế kỷ XIX (năm 1796, Nguyễn Ánh mới bắt đầu đúc tiền Gia Hung thông bảo). Nói một cách cụ thể hơn, khả năng lớn số tiền nói trên có mặt tại Păng Tiêng vào khoảng từ nửa sau thế kỷ XVIII đến đầu thế kỷ XIX.

2.4. Câu hỏi hóc búa nhất là chủ nhân của số tiền cổ nói trên là ai? Như đã nói ở phần đầu, những người dân thiểu số vùng này (Cơ ho, M'nông, Mạ...) vào các thế kỷ XVIII - XIX và cả cho tới giữa thế kỷ XX vẫn chưa sử dụng tiền làm vật ngang giá trong trao đổi hàng hóa. Trong trao đổi với chúng tôi, đồng bào địa phương ở đây đều cho rằng số tiền ở đây là của người Chăm. Tuy nhiên, người Chăm mặc dù đã đạt trình độ tổ chức quốc gia và giao thương khá phát triển, nhưng các nguồn tài liệu thư tịch Trung Hoa cũng như bia ký Chăm đều không đề cập tới các cư dân Vương quốc Chăm pa trước đây có sử dụng tiền trong thương mại, nhất là tiền của người Việt và của người Hán. Theo GS. Lương Ninh, các nguồn tài liệu chỉ mới nói đến ở Chăm pa trao đổi bằng hiện vật ${ }^{10}$. Vậy phải chăng chủ sở hữu số tiền nói trên là người Việt? Theo GS. Đặng Nghiêm Vạn, vào thế kỷ thứ XVIII, cộng đồng Việt đầu tiên mới xuất hiện ở An Khê (Gia Lai). Vùng đất Lạc Dương, Lâm Đồng ngày nay vào các thế kỷ XVII - XVIII là

\footnotetext{
${ }^{10}$ Lương Ninh, Vương quốc Chăm pa, NXB Đại học Quốc gia Hà Nội, 2006, tr. 145
} 
địa bàn cư trú của các nhóm địa phương của tộc người Cơ ho (Srê, Cil, Lạch). Ngay cao nguyên Lang Bian cũng chỉ mới được Bác sỹ $\mathrm{A}$. Yersin khám phá vào năm 1893.

Căn cứ vào thanh gươm mà anh Đàm Văn Quang tìm thấy ở trên cùng với ghi chép trong bộ chính sử Đại Nam thực lục của triều Nguyễn và những tư liệu của nhà nghiên cứu người Pháp $\mathrm{A}$. Leclère, có thể suy đoán, chủ nhân (hay các chủ nhân) của số tiền cổ ở Păng Tiêng có liên quan tới những quý tộc Chăm pa thuộc trấn Thuận Thành (vùng Ninh Thuận, Bình Thuận ngày nay). Tuy vương quốc Chăm pa đã bị chúa Nguyễn "xóa sổ" từ 1692 sau cuộc vùng dậy cuối cùng của vua Bà Tranh, nhưng một số quý tộc Chăm pa vẫn không khuất phục chính sách đồng hóa của các chúa Nguyễn. Thi thoảng họ vẫn quy tập dân chúng, tổ chức những cuộc tấn công vào các phủ thành của chúa Nguyễn vùng Thuận Thành, nhất là vị tù trưởng Ba Phủ có tên là Toàn Phù. Trong 2 năm 1796, 1797 Toàn Phù 5 lần công kích các phủ thành thuộc vùng kiểm soát của Nguyễn Ánh. Tuy bị đánh dẹp, song hẳn là trong những cuộc tấn công đó, họ đã thu được khá nhiều "chiến lợi phẩm", trong đó có cả tiền bạc của quan lại người Việt ở các phủ thành đó. Để tránh sự truy nã của quan quân người Việt, một số vương công quý tộc Chăm pa có thể đã mang theo thuộc hạ và tiền của chạy trốn lên miền núi sống với các cư dân thiểu số ở đây một thời gian trước khi tỵ nạn sang Campuchia ${ }^{11}$. Vùng đất Păng Tiêng là một điểm dừng của họ trên đường lánh nạn và trước lộ trình sang vùng đất mới, họ đã chôn lại số tiền cướp được tại đây, vì ở vùng đất họ dự định tới không sử dụng loại tiền này. Thanh kiếm anh Quang tìm được rất có thể là bảo vật hoàng gia Chăm pa do vua Xiêm ban tặng. Những mâu thuẫn giữa các quốc gia Chân Lạp và Xiêm La thời đó cũng có thể là lý do mà họ không muốn mang theo thanh gươm đó. Tuy vậy, cũng không loại trừ khả năng số tiền cổ này có nguồn gốc từ hoạt động trao đổi, buôn bán của giới quý tộc, nhà buôn giàu có người Chăm với người Việt trong quá trình cư trú xen kẽ của hai cộng đồng cư dân này vào các thế kỷ XVII - XVIII, khi lãnh thổ Chăm pa được hội nhập mạnh mẽ vào lãnh thổ Đại Việt.

\footnotetext{
${ }^{11}$ Quốc sử quán triều Nguyễn, Đại Nam thục lục, Tập I, NXB Giáo dục, Hà Nội, 2004, tr. 345 - 348 (bản dịch của Viện Sử học, Viện Khoa học xã hội Việt Nam); A. Leclère, Histoire du Cambodge depuis le $1^{\text {er }}$ siècle de notre ère, Paris, 1914, tr.474. Dẫ் theo: Nguyễn Văn Luận, Người Chàm Hồi giáo miền Tây Nam phần Việt Nam, Bộ Văn hóa, Giáo dục và Thanh niên, Sài Gòn, 1974, tr. 30; Lương Ninh, Sách đã dẫn, tr. 244.
} 
Trên đây là một số suy nghĩ bước đầu của chúng tôi liên quan tới số tiền cổ mà người dân ở thôn Păng Tiêng tìm thấy trong những năm gần đây. Mục đích chủ yếu của chúng tôi là thông báo về một nguồn tư liệu mới chưa từng đề cập tới trong các công trình nghiên cứu về lịch sử Lâm Đồng nói riêng và Tây Nguyên nói chung. Cũng cần lưu ý, trong một số di chỉ mộ táng được khai quật trong những thập niên vừa qua trên đất Lâm Đồng, số hiện vật là tiền cổ tìm được cũng rất ít (Cát Tiên - 1 đồng, Đại Lào 1 đồng, Đạ Đờn -1 đồng, Đại Làng - 10 đồng) ${ }^{12}$. Rõ ràng, sự có mặt hiếm hoi của tiền cổ tại các di chỉ nói trên còn mang tính ngẫu nhiên hoặc nhiều lắm cũng chỉ với tư cách là tế phẩm hay là đồ tùy táng. Trái lại, sự tìm thấy ở Păng Tiêng số tiền cổ với số lượng lên tới hàng tạ hoàn toàn là một thông tin lần đầu tiên được biết đến ở Lâm Đồng. Một vài giả thuyết mà chúng tôi mạnh dạn nêu lên chỉ hoàn toàn có tính tham khảo cho những dự kiến nghiên cứu tiếp theo. Để làm sáng tỏ vấn đề, không thể không tiến hành những cuộc khảo sát thực địa dài ngày và khai quật khảo cổ học trên đất Păng Tiêng để tìm thêm những nguồn tư liệu mới. Chúng tôi đã trao đổi vấn đề này với lãnh đạo Bảo tàng tỉnh Lâm Đồng và hy vọng sẽ dành được sự quan tâm của các nhà quản lý cũng như giới khoa học trong và ngoài tỉnh cùng hợp tác nghiên cứu.

\section{TÀI LIỆU THAM KHẢO}

[1] Trần Văn Bảo, Khảo cổ học tiền-sơ sư và lịch sủ Lâm Đồng, NXB Khoa học Xã hội, Hà Nội, 2014.

[2] Nguyễn Văn Luận, Nguời Chàm Hồi giáo miền Tây Nam phần Việt Nam, Bộ Văn hóa, Giáo dục và Thanh niên, Sài Gòn, 1974.

[3] Đỗ Văn Ninh, Tiền cổ Việt Nam, NXB Khoa học xã hội, Hà Nội, 1992.

[4] Lương Ninh, Vuơng quốc Chăm pa, NXB Đại học Quốc gia Hà Nội, 2006.

[5] Phạm Quốc Quân (chủ biên), Tiền kim loại Việt Nam, Bảo tàng Lịch sử Việt Nam xuất bản, Hà Nội, 2005.

\footnotetext{
${ }^{12}$ Nguyễn Khắc Sử, Khảo cổ học tiền sủ Tây Nguyên, NXB Giáo dục, Hà Nội, 2007, tr. 5, 172, 173, 174; Trần Văn Bảo, Khảo cổ học tiền-sơ sủ và lịch sủ Lâm Đồng, NXB Khoa học Xã hội, Hà Nội, 2014, tr. 137 - 138, 145, 146, 156-157.
} 
[6] Quốc sử quán triều Nguyễn, Đại Nam thục lục, tập I, (bản dịch của Viện Sử học, Viện Khoa học xã hội Việt Nam), NXB Giáo dục, Hà Nội, 2004.

[7] Nguyễn Khắc Sử, Khảo cổ học tiền sử Tây Nguyên, NXB Giáo dục, Hà Nội, 2007.

[8] Đặng Nghiêm Vạn, "Bàn về lịch sử tộc người và đặc điểm kinh tế, xã hội, văn hóa cư dân Tây Nguyên", Tạp chí Dân tộc học, số 3/1980.

\title{
SOME INITIAL COMMENTS ABOUT ANCIENT COINS FOUND IN PANG TIENG VILLAGE (LAT COMMUNE, LAC DUONG DISTRICT, LAM DONG PROVINCE)
}

\author{
Cao The Trinh ${ }^{a^{*}}$, Nguyen Huy Khuyen ${ }^{a}$, Mai Minh Nhat ${ }^{b}$ \\ ${ }^{a}$ The Faculty of International Studies, Dalat University, Lamdong, Vietnam \\ ${ }^{a}$ The Faculty of History, Dalat University, Lamdong, Vietnam \\ *Corresponding author: trinhct@dlu.edu.vn \\ Article history \\ Received: January $22^{\text {nd }}, 2016$ \\ Received in revised form: January $30^{\text {th }}, 2016$ \\ Accepted: March $16^{\text {th }}, 2016$
}

\begin{abstract}
In recent years, Pang Tieng villagers (Lat Commune, Lac Duong District, Lam Dong Province) have found quintals of ancient coins. Only a small amount of them remains while the rest was lost (because of scrapselling). With 416 remained ancient coins, the authors have verified 42 ancient coin names, including a number of Vietnamese names (An Phap Nguyen Bao, Canh Hung Thong Bao...), and many those of Chinese currency (coin names in the age of the Tang, Northern Song, Ming and Qing dinasties). It is possible that the coins found are stolen by Champa aristocracy in the attacks on the palace of Nguyen Lords in Thuan Thanh in the end of eighteenth century. In order to avoid the arrest of Nguyen Lords, the Chams resided temporarily in Pang Tieng. Later, the Chams buried the money in Pang Tieng before taking refuge in Cambodia.
\end{abstract}

Keywords: Ancient coins; Ancient coins found in Pang Tieng; Ancient coins in the Central Highlands; Vietnamese ancient coins; Chinese ancient coins. 